\title{
XRD study of the surface of aluminum alloy AK5M7 after electric-spark alloying
}

\author{
I. K. Hasan ${ }^{\dagger, 1}$, N. A. Pan'kin², V. M. Kyashkin² \\ ${ }^{\dagger}$ srorismael@gmail.com \\ ${ }^{1}$ Ministry of Science and Technology, Baghdad, 10071, Iraq \\ ${ }^{2}$ National Research Mordovian State University, Saransk, 430005, Russia
}

\begin{abstract}
The article presents the results of X-ray diffraction studies of the phase composition, substructure, and residual stresses in the surface layer of the AK5M7 alloy for different energy levels during electric-spark alloying (ESA) using a copper electrode. The micro-distortion values were estimated from the parameters of the crystal lattice of phase grains for which different reflection planes are parallel to the sample surface. Three phases, i.e., aluminum, silicon, and the intermetallic compound $\left(\mathrm{Al}_{2} \mathrm{Cu}\right)$, were found, and the fraction of the intermetallic compound increases with the ESA energy. It could be reasoned to intensify micro-metallurgical processes in the modified layer due to high thermomechanical effects. The residual stresses are tensile for $\mathrm{Al}$ and compressive for $\mathrm{Al}_{2} \mathrm{Cu}$. The ESA energy at about $0.39 \mathrm{~J}$ yielded maximum stresses. Due to the large temperature gradient, variant thickness and specific volume/density were observed over the modified layer. An increase in the ESA energy resulted in the formation of the chaotic distribution of grains. The energy model qualitatively explains the emergence of one or another preferred orientation in electric-spark coatings based on the ratio between the surface and deformation energies. The results obtained are beneficial for improving surface modification of low-melting materials by electric-spark treatment and for optimizing the process.
\end{abstract}

Keywords: electric-spark alloying, phase composition, substructure, microstresses, preferential orientation.

УДК: 621.9.648.4

\section{Рентгенографическое исследование поверхности алюминиевого сплава АК5М7 после электроискровой обработки}

\author{
Хасан И.Х. ${ }^{\dagger, 1}$, Панькин Н. А. ${ }^{2}$, Кяшкин В. М. ${ }^{2}$ \\ ${ }^{1}$ Министерство науки и технологий, Багдад, 10071, Ирак \\ ${ }^{2}$ Мордовский государственный университет им. Н. П. Огарёва, Саранск, 430005, Россия
}

В статье представлены результаты рентгенографических исследований фазового состава, субструктуры и остаточных напряжений в поверхностном слое сплава АК5М7 в зависимости от энергии электроискровой обработки (ЭИО) медным электродом. Оценку величины макронапряжений проводили из параметров кристаллической решётки зерен фазы, для которых разные плоскости отражения параллельны поверхности образца. Обнаружено присутствие трех фаз: алюминия, кремния и интерметаллического соединения $\mathrm{Al}_{2} \mathrm{Cu}$. Увеличение энергии ЭИОприводит к росту доли интерметаллида, величины микродеформаций и уменьшению размеров субблоков. Данный факт объясняется интенсификацией в модифицируемом слое микрометаллургических процессов из-за высоких термомеханических воздействий. Для алюминия остаточные напряжения растягивающие, а для $\mathrm{Al}_{2} \mathrm{Cu}-$ сжимающие. Они достигают экстремальных значений при энергии ЭИО порядка 0.39 Дж. Причинами возникновения остаточных напряжений можно назвать наличие большого градиента температур по толщине модифицированного слоя, многофазность (каждая фаза имеет различные коэффициенты теплового расширения) и изменения удельного объема/плотности. Полученные результаты могут быть использованы при совершенствовании теорий модификации поверхности легкоплавких материалов электроискровой обработкой и оптимизации соответствующего технологического процесса.

Ключевые слова: электроискровая обработка, фазовый состав, субструктура, макронапряжения, преимущественная ориентация. 


\section{Introduction}

Aluminum-based composites and alloys are the most commonly used materials due to their low weight and high strength virtue. The exposure to various operational factors like thermal, tribological, and aggressive media leads to the destruction and failure of their surface. However, various physicochemical methods like electrical contact welding, spraying coatings by thermal, gas-dynamic, gas-plasma methods, electric-spark alloying, etc. are being utilized to improve the surface characteristics. Electric-spark alloying (ESA) of the surface layer [1], based on the destruction of cathode material and its transfer it through a gaseous medium to the processed product (anode), is one of the most promising methods. In this case, the interelectrode space (spark channel) temperature ranges from 5000 to $10000^{\circ} \mathrm{C}$. Despite the relative simplicity of this method and the plethora of research works [2-8], there are still unrevealed concerns about the physical and chemical processes occurring during the formation of the structure and the effect of electric-spark treatment on the properties of the modified material.

In this work, AK5M7 alloy was processed through electric spark alloying with a copper electrode at a different energy, and the phases were detected by X-ray diffraction. The phase composition was revealed through analyzing the variations in the position, intensity, and breadth of peaks and by determining the magnitude of residual stresses.

\section{Material and methods}

Electric-spark processing at different energies was carried out on the AK5M7 alloy (parallelepiped, $15 \times 15 \times 4 \mathrm{~mm}^{3}$ ) as a substrate using a wire electrode (commercially pure copper). The chemical composition of the alloys (Al - 88 at.\%, $\mathrm{Si}-5$ at.\% and $\mathrm{Cu}-7$ at.\%) was determined using an ARL PERFORM'X 4200 spectrometer. Moreover, the roughness of the treated surface did not exceed $0.32 \mu \mathrm{m}$. X-ray diffraction studies were performed on an Empyrean PANalytical with copper radiation. The processing of X-ray diffraction patterns was carried out using the High Score Plus software package directly linked to the PDF-2 powder materials X-ray database.
Residual stresses were estimated based on the analysis of the parameters of the crystal lattice of phase grains in which different reflection planes are parallel to the sample surface $[9,10]$. In this case, the magnitude of micro stresses $\sigma$ can be found from the following expression (Eq. 1):

$$
\sigma=\frac{a_{1}-a_{2}}{2\left(a_{2} K_{1}-a_{2} K_{1}\right)},
$$

where $K_{1}, K_{2}$ are the X-ray elastic constants for the directions $h_{1} k_{1} l_{1}$ and $h_{2} k_{2} l_{2}$ in the crystal lattice with periods $a_{1}$ and $a_{2}$, respectively. The value $K=(\mu / E)_{h k l}$ ( $\mu, E$ are Poisson's ratio and Young's modulus for a given crystallographic direction $(h k l)$, respectively) was determined using the IsoDEC program [11]. The initial data were single-crystal elastic compliance constants $S_{i j}$ of the materials under study $[12,13]$.

The lattice parameter $a$ for a cubic crystal evaluated from the interplanar distance $(d)$ in the $(h k l)$ direction:

$$
a=d \sqrt{h^{2}+k^{2}+l^{2}} \text {. }
$$

Furthermore, in the case of the tetragonal phase, the reduced values of $x$ periods $a$ and $c$ of the crystal lattice $x=c / a$ were used [10]:

$$
a=d \sqrt{\left(h^{2}+k^{2}\right) x^{2}+l^{2}} / x .
$$

Besides, the parameters of the substructure (microstrains $\varepsilon$ and the size of the subblocks $D$ ) were determined from the full-profile analysis of XRD patterns using the Rietveld refinement method [14].

\section{Results}

Fig. 1 shows the X-ray diffraction patterns of the AK5M7 alloy before and after its electric-spark treatment.

The examination of X-ray patterns indicates that the studied samples are crystallized in differentphases. Al (facecentered lattice with the symmetry group Fm3m), Si (cubic lattice with space group $\mathrm{Fd} 3 \mathrm{~m}$ ), and intermetallic compound $\mathrm{Al}_{2} \mathrm{Cu}$ (tetragonal crystal lattice with space group $\mathrm{I} 4 / \mathrm{mcm}$ ) were found from the XRD pattern of the modified layer, which are the typical phases for the initial AK5M7 alloy. Changes were observed in the intensity, width, position, and Bragg angle of the peaks with the energy of ESA.

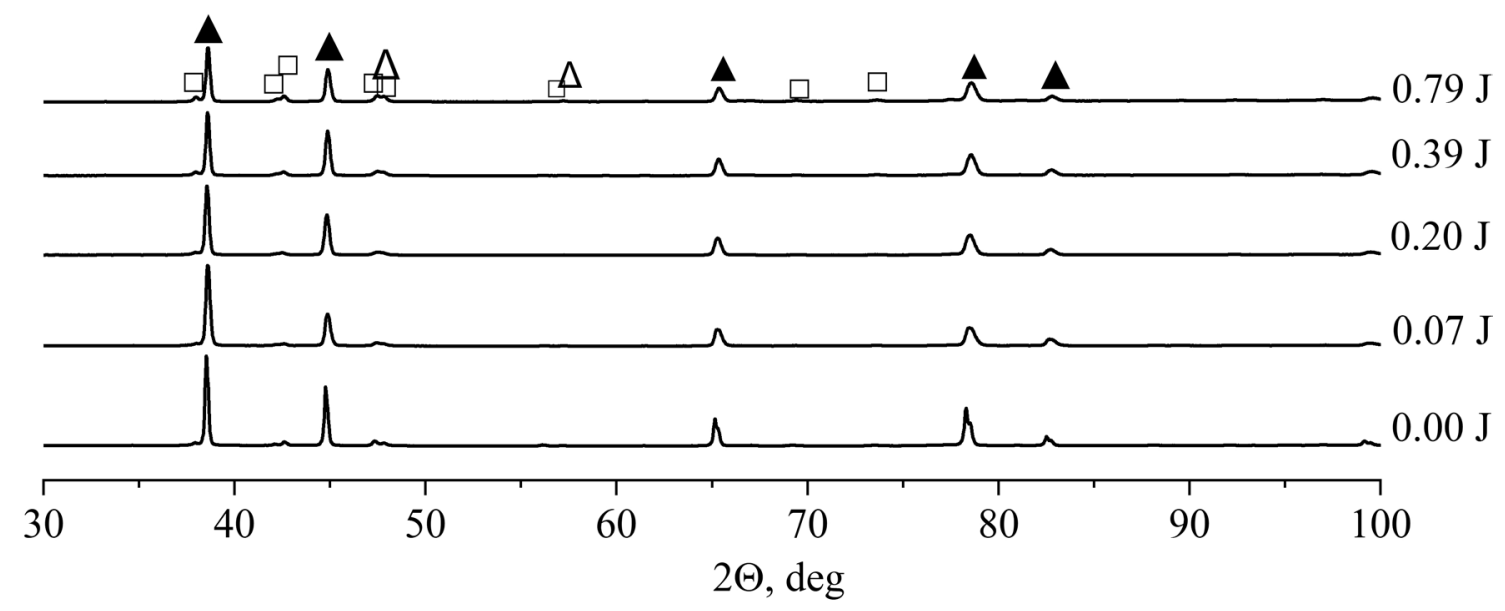

Fig. 1. Areas of the X-ray diffraction pattern from the initial alloy and after its ESA (phase lines: $\boldsymbol{\Delta}-\mathrm{Al} ; \square-\mathrm{Al} 2 \mathrm{Cu} ; \Delta-\mathrm{Si}$ ). 
One can see a monotonic increase in the sum of integrated intensities of diffraction peaks from above mentioned phases with an increase in the energy $E$ of electric-spark treatment. Changes in the intensity of the Si phase are in significant.

The broadening of the diffraction lines is due to the parameters of the substructure: microdistortion $\varepsilon$ and the small size of the subblocks $D$ (crystallite size). Fig. 2 represents the variation of $D$ and $\varepsilon$ with the energy. It is noticed that an increase in $E$ leads to a rise in microstrains and a reduction in the size of the subblock. Further, changes in $D$ and $\varepsilon$ are more intense for the intermetallic phase $\mathrm{Al}_{2} \mathrm{Cu}$.

Fig. 3 exhibits the variation of residual stresses $(\sigma)$ in the modified surface layer of AK5M7. The stresses of aluminum and the intermetallic compound phases were obtained by averaging over a depth of about 15-17 $\mu \mathrm{m}$, determined by X-ray radiation for the considered Bragg angles [14]. Furthermore, the residual stresses for the aluminum phase are tensile and reach their maximum values at $E=0.39 \mathrm{~J}$. In contrast, the microstresses for $\mathrm{Al}_{2} \mathrm{Cu}$ are compressive, and the minimum value (modulo) corresponds to $E=0.39 \mathrm{~J}$.

However, the substructure parameters for the Si phase were not distinguished, and hence the stresses could not be evaluated. This is due to the low intensity of diffraction lines for this phase, which leads to a large error in determining the corresponding parameters.

Additionally, the ratios in the integrated intensities for each phase were used to calculate their content in the test material. Table 1 shows the fractions of phases calculated from the analysis of intensities in the surface layer of the AK5M7 alloy before and after its ESA.

An increase in the ESA energy leads to the growth of $\mathrm{Al}_{2} \mathrm{Cu}$ intermetallic phase in the surface layer (Table 1). Si phases were diluted to the fourth part of the initial content after ESA. Besides, an increase in the integral intensity of the aluminum phase with a decrease in its content in the surface layer indicates an increase in the volume of aluminum crystallites irradiated by X-ray radiation. This fact, first of all, indicates a decrease in the thickness of the modified layer as the energy of electric-spark processing increases. This is in-line with the previous work [2], which concludes in loss of weight with the ESA energy. The study showed erosion of the treated surface, whereas an increase in the processing energy led to an increase in the weight loss of the samples.

Fig. 4 shows the ratios of the intensity $I(h k l)$ from the reflection with indices $(h k l)$ to the total intensity $I_{\Sigma}$ of all diffraction maxima of the phase under consideration. We presented the results for the three strongest lines.

The data on aluminum indirectly indicate some preferred orientation of aluminum grains in the (111) direction with a low transformation energy, this is explained by the ratio

Table 1. Phase composition of the surface after ESA.

\begin{tabular}{|c|c|c|c|}
\hline \multirow{2}{*}{ Energy } & \multicolumn{3}{|c|}{ Phase concentration, \% } \\
\cline { 2 - 4 } & $\mathrm{Al}$ & $\mathrm{Al}_{2} \mathrm{Cu}$ & $\mathrm{Si}$ \\
\hline AK5M7 & 94 & 2 & 4 \\
\hline 0.07 & 97 & 2 & 1 \\
\hline 0.20 & 96 & 2 & 1 \\
\hline 0.39 & 94 & 5 & 1 \\
\hline 0.79 & 89 & 10 & 1 \\
\hline
\end{tabular}

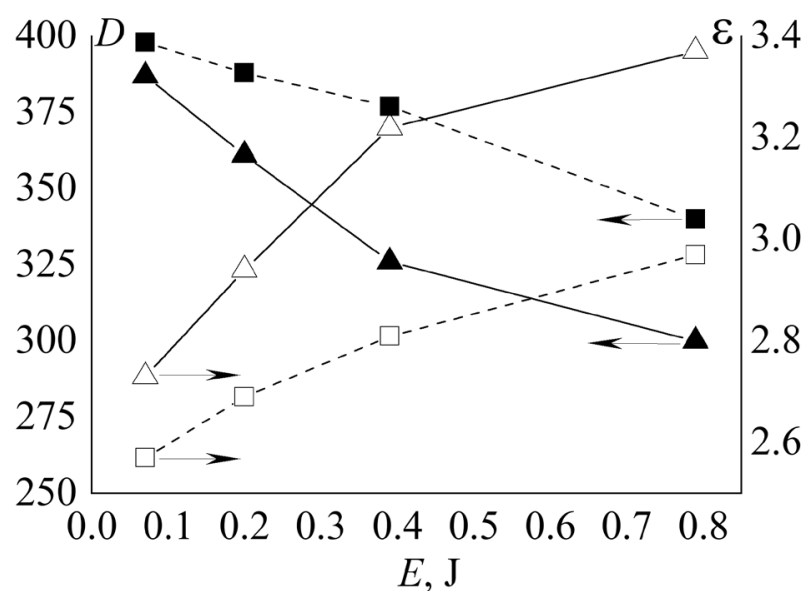

Fig. 2. Effect of energy on the magnitude of microstrains $\varepsilon\left(10^{-3}\right)$ and the size of subblocks $D(\mathrm{~nm})$. ( $\left.\mathbf{\square}, \square-\mathrm{Al} ; \boldsymbol{\Delta}, \Delta-\mathrm{Al}_{2} \mathrm{Cu}\right)$.

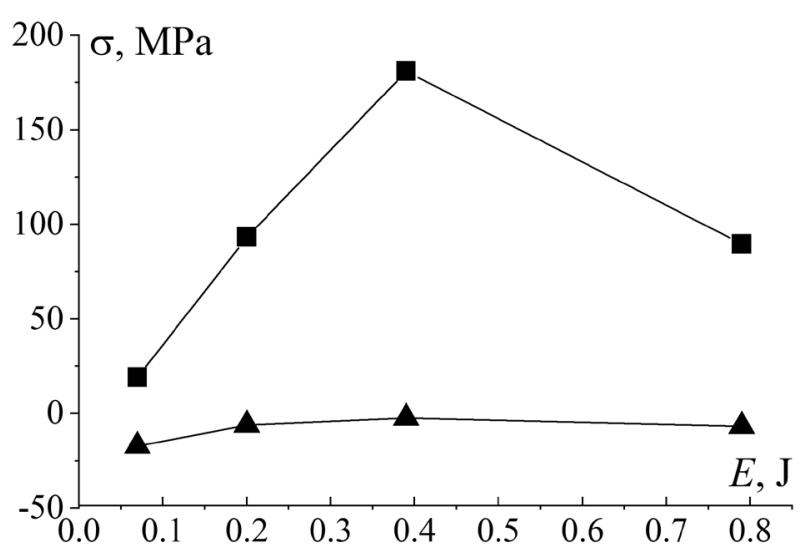

Fig. 3. Effect of energy on residual stresses $\sigma$ in aluminum ( $\mathbf{})$ and $\mathrm{Al}_{2} \mathrm{Cu}(\mathbf{\Delta})$.

$I(111) / I_{\Sigma}$ (in our case 0.65 to 0.50 with an increase in $E$ ) that is higher than the corresponding value for the powder material (0.44 - according to this PDF-2 file).

A further increase in $E$ leads to a more chaotic orientation, i.e., the intensity ratio $I(h k l) / I_{\Sigma}$ becomes close to the corresponding data for powder materials (no texture for them). For the intermetallic compound, there is also a random tendency during crystallization growth.

\section{Discussion}

Electric-spark processing resulted from the formation of conduction channels between the sliding contact of the electrodes due to the release of Joule heat and the subsequent explosion of the contact, which ensure the formation of a reflow bridge. Furthermore, local areas of the electrode surface experience high mechanical and thermal effects $[1,3]$ after ESA, due to which high pressure and temperature arise, which leads to plastic flows and deformations, as the conditions at contact were more feasible for the substrate (aluminum) and electrode (copper) materials. Also, high values of thermal conductivity contributed to a high rate of heat transfer, due to which a large temperature gradient 
occurred between the surface and the underlying layers. Besides, within a layer of the order of several micrometers, the temperature rapidly decreases to the corresponding temperatures of phase transitions and transformations of the electrode and substrate materials and at the boundary of their contact. Consequently, micro metallurgical processes, diffusion, and chemical interaction were intensified in the alloyed layer. They lead to the formation of extremely nonequilibrium structures with a small grain size, high heterogeneity in composition, structural properties. In particular, intermetallic compounds of the "Cu-Al" system are formed. In our case, $\mathrm{XRD}$ analysis revealed the presence of only the $\mathrm{Al}_{2} \mathrm{Cu}$ phase. Simultaneously, the existence of other phases of the above-mentioned system is quite possible, which could not be detected, as their contents are less than the detection limit of the XRD method [14].

The emergence of the preferred orientation in the coatings qualitatively explains the energy model proposed in [15] and developed by others authors $[16,17]$. In this way, the presence of one texture or another is associated with the ratio between the surface and deformation energies. The first of them is determined by the number of broken bonds $N_{h k l}$. The deformation energy depends on the values of Young's modulus and (to a lesser extent) Poisson's ratio, as well as on the magnitude of microstrains (quadratic dependence).

In our case, the treatment by low energy electrosparking (Fig. 3), the magnitude of the microstrain is minimal and the size of the subblocks is maximal. Therefore, the value of $N_{h k l}$ is minimal. As the quadratic dependence of the deformation energy on $\varepsilon$, it takes precedence over that of the surface according to [17], this situation promotes the formation of a preferential orientation in the (111) direction for the cubic phase (aluminum). In our case, at $E=0.07 \mathrm{~J}$, a maximum of the ratio $I(111) / I_{\Sigma}$ was observed. A decrease in the size of the sub-grains leads to an increase in the number of broken bonds and, consequently, to an increase in the surface energy. As a result, it will be progressively compared to the deformation. This fact will contribute to the chaotic orientation of the grains. In the case where the surface energy predominates, a preferential orientation in the (200) direction will be formed (for a cubic crystal) [17].

Furthermore, an increase in the energy of electricspark processing leads to an increase in the share of Joule heat. As a consequence, part of the substrate and electrode melts and vaporizes. As the boiling point of $\mathrm{Al}\left(2450^{\circ} \mathrm{C}\right)$ is relatively lower than of copper $\left(2700^{\circ} \mathrm{C}\right)$, due to which $\mathrm{Al}$
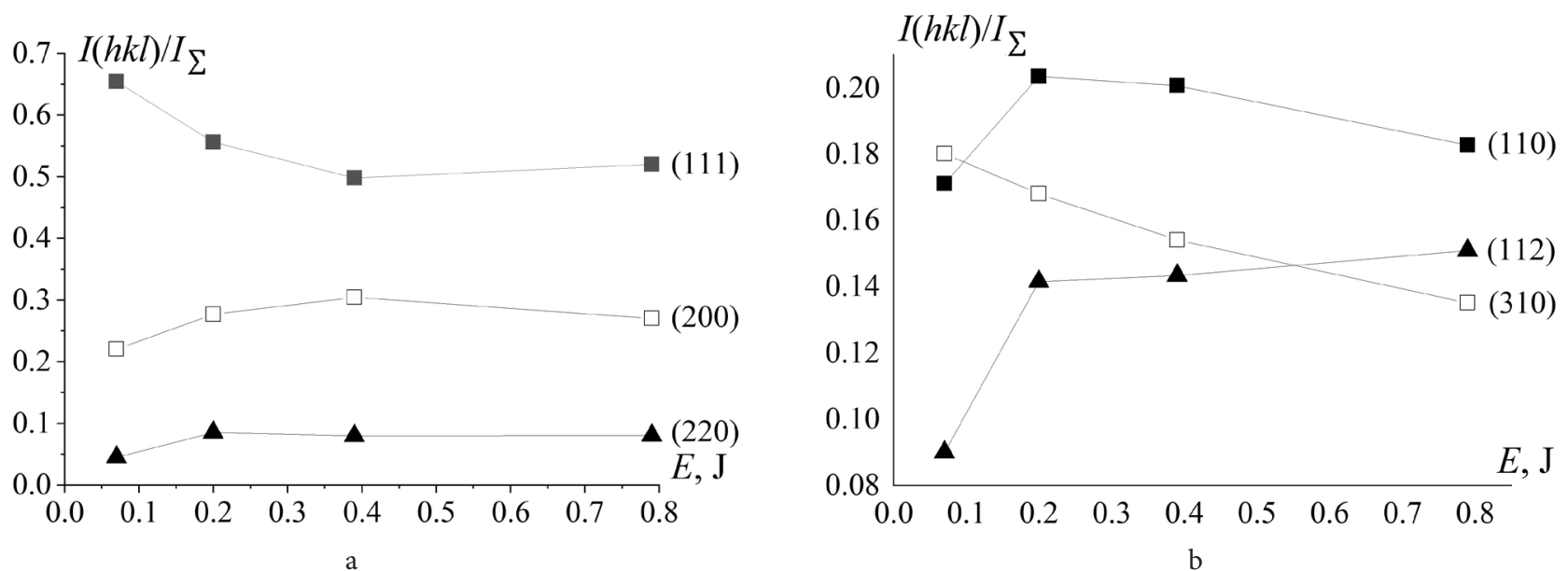

Fig. 4. Effect of energy on the ratio of the intensity of the reflection $I(h k l)$ in the direction $(h k l)$ to the total intensity of all reflections of a given phase $I_{\Sigma}$ for aluminum (a); for $\mathrm{Al}_{2} \mathrm{Cu}(\mathrm{b})$.
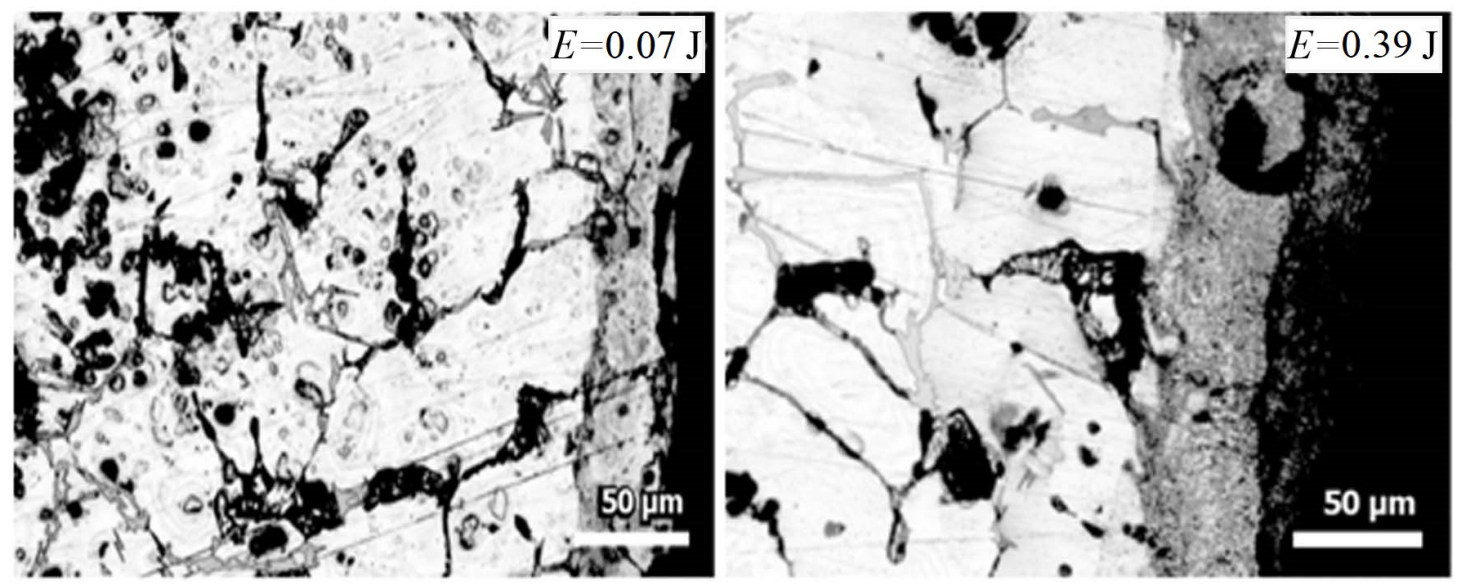

Fig. 5. Microstructure of the AK5M7 alloy after ESD. 
predominantly evaporates and is accompanied by an increase in erosion. The microstructure of the obtained alloys (Fig. 5) indicates the presence of different surface forms after ESD.

Moreover, an increase in the ESA energy leads to an increase in the zone exposed to significant thermomechanical effects with the transition of materials to a liquid state and its more intensive mixing. The consistency of the silicon fraction indirectly supports it. Additionally, this phase is initially present only in the substrate material (aluminum alloy). Moreover, cooling, due to heat removal through conduction (predominantly) and thermal radiation, leads to the formation of many crystallization centers. Consequently, an ultra-dispersed and fine-crystalline structure is formed with a high degree of deformation of crystallites of the forming phases and a high density of dislocations i. e. large microstrains appear.

Local formation of a strongly disordered state close to amorphous is possible, which cannot be detected by X-ray. Besides, a larger volume exposed to thermomechanical action leads to an increase in mass transfer between the components of the system under consideration. Eventually, this will lead to an increase in the contact area of the substrate and electrode materials. An increase in the contact area resulted in the formation of intermetallic compounds, "copperaluminum" system i.e. a higher content of the $\mathrm{Al}_{2} \mathrm{Cu}$ phase. The predominant evaporation of aluminum contributes to a larger processed volume of $\mathrm{Cu}$, which increases with an increase in the ESA energy. This fact leads to an increase in the crystallization centers of $\mathrm{Cu}$, which has a higher melting point, and the formation of a more finely dispersed structure.

One of the main reasons for residual stresses is the presence of a large temperature gradient across the thickness of the modified layer. In this case, the appearance of microstresses is associated with thermal expansion/contraction and the temperature dependence of the linear coefficient of thermal expansion (CTE). As mentioned above, the materials under study are multiphase systems and have different CTE values [18]. As a result, thermal stresses appear at phase boundaries due to the difference between CTE values of contacting materials. Due to the chaotic orientations of grains of the formed phases, in particular, at high energies of ESA, a partial compensation of these stresses is possible. In addition, structural factors also contribute to the stress state.

A decrease in the grain size and the proportion of the intermetallic phase with an increase in $E$ is accompanied by an increase in the area of interphase and grain boundaries. The above mentioned fact leads to a change in the residual stresses as their growth is observed. The formation of the intermetallic compound is accompanied by a change in the specific volume/density. This fact also contributes to the occurrence of microstresses in the materials under investigation.

\section{Conclusion}

The study concludes as follows. First of all, the X-ray diffraction method revealed the presence of the following phases: aluminum $\mathrm{Al}(\mathrm{Fm} 3 \mathrm{~m})$, silicon $\mathrm{Si}(\mathrm{Fd} 3 \mathrm{~m})$, an intermetallic compound $\mathrm{Al}_{2} \mathrm{Cu}(\mathrm{I} 4 / \mathrm{mcm})$ in the modified layer. An increase in the energy of electric-spark processing is accompanied by an increase in the fraction of the intermetallic phase $\mathrm{Al}_{2} \mathrm{Cu}$. Moreover, the broadening of diffraction lines for the detected phases is associated with the parameters of the substructure. It is noted that an increase in the processing energy leads to an increase in the magnitudes of microstrains and crystallite size. Besides, macro stresses for the entire range of investigated energies of electric-spark treatment in aluminum are tensile, and in the intermetallic compound $\mathrm{Al}_{2} \mathrm{Cu}-$ compressive. They reach extreme values at energies of the order of $0.39 \mathrm{~J}$. Finally, an increase in the energy of electric-spark processing leads to a chaotic distribution of the orientation of the grains of the crystallographic phases of aluminum and intermetallic compounds. We believe that the results of this article can be used to optimize the process of electric-spark alloying of aluminum alloys and to improve the theory of surface modification and the coatings creation for various purposes.

Acknowledgment. The authors express their special gratitude to the N.E. Fomin, N.P. Ogarev Mordovia State University, for support and discussion of the results.

\section{References}

1. S.A. Velichko, P.V. Senin, P.V. Chumakov. Increasing the Service Life of Piston Hydraulic Cylinders Using Electrospark Alloying. Saransk. Publishing house of Mordovian University (2016) 108 p. (in Russian) [С. А. Величко, П. В. Сенин, П. В. Чумаков. Повышение долговечности поршневых гидроцилиндров с применением электроискровой технологии. Саранск, Изд-во Мордов. ун-та (2016) 108 с.]

2. I.K. Hasan, N.E. Fomin. Hardening Technologies and Coatings. 15 (3), 139 (2019). (in Russian) [И.К. Хасан, H.Е. Фомин. Упрочняющие технологии и покрытия. 15 (3), 139 (2019).]

3. D. A. Ignat'kov. Elektronnaya obrabotka materialov. 37 (4), 9 (2001). (in Russian) [Д. А. Игнатьков. Электронная обработка материалов. 37 (4), 9 (2001).]

4. F. Kh.Burumkulov, V. P.Lyalakin,I. A.Pushkin,S. N.Frolov. Agricultural mechanization and electrification. 4, 23 (2001). (in Russian) [Ф.Х. Бурумкулов, В.П. Лялякин, И.А. Пушкин, С.Н. Фролов. Механизация и электрификация сельского хозяйства. 4, 23 (2001).]

5. S. I. Smagin, V.D. Vlasenko, Yu. I. Mulin. Computational technologies. 14 (3), 79 (2009). (in Russian) [С. И. Смагин, В.Д. Власенко, Ю.И. Мулин. Вычислительные технологии. 14 (3), 79 (2009).]

6. A.D. Verkhoturov, V.I. Ivanov, L. A. Konevtsov. Proceedings of GOSNITI. 107 (2), 131 (2011). (in Russian) [А. Д. Верхотуров, В. И. Иванов, Л. А. Коневцов. Труды ГОСНИТИ. 107 (2), 131 (2011).]

7. V.D. Vlasenko, M. V. Kolisova. Contemporary engineering sciences. 9 (6), 249 (2016). Crossref

8. E. V. Yurchenko, V.I. Ivanov. Proceedings of GOSNITI. 117 (3), 251 (2014). (in Russian) [Е.В. Юрченко, В. И. Иванов. Труды ГОСНИТИ. 117 (3), 251 (2014).]

9. S. Ya. Betsofen, L. M. Petrov, A.A. Ilyin, I. O. Bannyh, A.N. Lucenko. Surface Investigation: X-Ray, Synchrotron and Neutron Techniques. 1, 39 (2004). (in Russian) [С.Я. Бецофен, Л.М. Петров, А.А. Ильин, 
И. О. Банных, А. Н. Луценко. Поверхность. Рентгеновские, синхротронные и нейтронные исследования. 1, 39 (2004).]

10. S. Ya. Betsofen, A.A. Ashmarin, A.A. Lozovan, B.V. Ryabenko, A.N. Lutsenko, A.M. Mamonov, D. E. Molostov. Surface Investigation: X-Ray, Synchrotron and Neutron Techniques. 7, 33 (2016). (in Russian) [С. Я. Бецофен, А. А. Ашмарин, А. А. Лозован, Б. В. Рябенко, А. Н. Луценко, А. М. Мамонов, Д.Е. Молостов. Поверхность. Рентгеновские, синхротронные и нейтронные исследования. 7, 33 (2016).] Crossref

11. T. Gnaupel-Herold. J. Appl. Cryst. 45, 573 (2012). Crossref

12. S. Wang, C. Fan. Metals. 9, 1037 (2019). Crossref

13. H. Liu, I. Papadimitriou, F.X. Lin, J. L. Lorca. Acta Materialia. 167, 121 (2019). $\underline{\text { Crossref }}$
14. Ya. S. Umansky. X-Ray of metals. Moscow, Metallurgiya (1967) 235 p. (in Russian) [Я.С. Уманский. Рентгенография металлов. Москва, Металлургия (1967) 235 с.]

15. J. Pelleg, L.Z. Zevin, S. Lungo, N. Croitoru. Thin Solid Films. 197, 17 (1991). $\underline{\text { Crossref }}$

16. B. Rauschenbach, J.W. Gerlach. Cryst. Res. Technol. 35 (6-7), 675 (2000). Crossref

17. J. P. Zhao, X. Wang, Z. Y. Chen. J. Phys. D: Appl. Phys. 30, 5 (1997). Crossref

18. V.K. Afanasyev, A.V. Gorshenin, M.A. Starostina, I. V. Degtyareva, E. V. Pervakova. Metallurgy of mechanical engineering. 3, 30 (2010). (in Russian) [В.К. Афанасьев, А. В. Горшенин, М.А. Старостина, И.В. Дегтярева, Е. В. Первакова. Металлургия машиностроения. 3, 30 (2010).] 